\title{
Can organisation development principles in India's local governments improve governance?
}

\author{
Commonwealth Journal of Local Governance \\ Issue 19: December 2016 \\ http://epress.lib.uts.edu.au/ojs/index.php/cjlg
}

\section{Sonali Srivastava}

Anode Governance Lab

Bengaluru, India

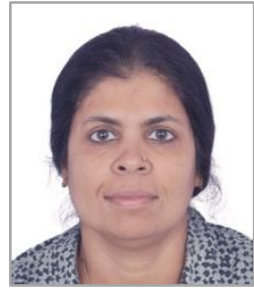

\section{Madhavi Rajadhyaksha}

Anode Governance Lab

Bengaluru, India

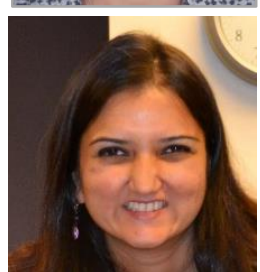

\begin{abstract}
This paper examines the application of organisation development principles to rural local selfgovernment bodies in Karnataka, India with the objective of developing their organisational capacity and improving their efficiency. The premise is that strong gram panchayats (village councils) can address issues hindering service delivery and governance at the grass roots.

The paper illustrates the methodology used in the development of an innovative framework called Gram Panchayat Organisation Development (GPOD) and its implementation in action research mode in two village councils since 2011. It further explores the wider applicability of this framework, which has been extended to over 50 gram panchayats (GPs) since 2014. GPOD works towards strengthening the panchayat as an organisation in its entirety, rather than by tackling stand-alone components. It includes building a shared vision in the panchayat, mapping and re-engineering key processes, developing accountability and incentive structures, and supporting the village body in developing and implementing its annual plans. The approach has evolved to its present form based on real-time change management initiatives in GPs in which politically elected members participated in decision-making and implementation. We argue that by following the principles of organisation development and aligning the panchayat's organisational components, marked improvements in local governance and service delivery were achieved. Impact is captured in terms of systemic outputs such as annual plans, accountability structures and activation of defunct committees, as well as improvements in services such as health, sanitation, drinking water, etc. The paper also includes a critique of the challenges faced as GPOD was scaled up to include new areas.
\end{abstract}

(C) 2016 Sonali Srivastava and Madhavi Rajadhyaksha. This is an Open Access article distributed under the terms of the Creative Commons Attribution 4.0 Unported (CC BY 4.0) License (https://creativecommons.org/licenses/by/4.0/), allowing third parties to copy and redistribute the material in any medium or format and to remix, transform, and build upon the material for any purpose, even commercially, provided the original work is properly cited and states its license. 


\section{Introduction}

Democratic decentralisation is woven into the historical fabric of Indian political life, and has been enshrined in the Constitution of India for over two decades. Globally, decentralisation has been credited for creating institutions that are more sensitised to local needs than state and national bodies by virtue of being closer to the people, and more accountable to citizens due to multi-level checks and balances. On the other hand, decentralisation has been criticised for facilitating the capture of resources by elites. At the outset, this paper acknowledges that decentralisation as a formal process involving transfer of power from the state to local bodies could differ from practice where political economy variables such as gender, caste and class exert huge influence on how local governments actually function (Bardhan 2002; Johnson 2003).

The earliest examples of local governments in India appear to be community assemblies mentioned in Vedic texts. From janapadas (small republics) in areas north of the river Ganga around $600 \mathrm{BC}$, to the Mauryan kingdoms where decisions were taken through sabhas (public gatherings), and village councils in the Chola kingdoms of south India, local self-governments traditionally took wide and varying forms across India. The earliest legislation backing decentralised local governance is the Bengal Local Self Government Act 1885, which constituted district local boards across the Bengal province a practice subsequently replicated by other regions including Bihar, Orissa, Assam and North West Province (Second Administrative Reforms Commission 2007).

It is important to point out that 'local government' is not a universal term and encompasses many diverse organisation types. It may include municipal corporations, municipalities, town boards, district panchayats, taluka (block) panchayats and gram panchayats, among others. This paper will use the term to refer to gram panchayats, ${ }^{1}$ as defined by the $73^{\text {rd }}$ amendment of the Constitution of India (Government of India 1992). These village bodies govern rural citizens, who comprise $68 \%$ of India's population (Census of India 2011). It is also pertinent to note that there may be significant variation in the form and functions of specific local government institutions. For example, the jurisdiction and functions of panchayats differ across Indian states in accordance with the individual state laws which govern them (Gabris and Golembiewski 1996).

Post-independence, democratic decentralisation was established, initially through Article 40 of the Constitution of India which enshrines the Directive Principles of State Policy. It directs that the state should organise and empower village panchayats to function as units of local self-government (The Constitution of India 1949). However, the provision was largely advisory in nature, and panchayats failed to capture public imagination as people's bodies. A need for a clearer mandate was felt. This was

\footnotetext{
1 As per the Constitution ( $73^{\text {rd }}$ Amendment) Act 1992, 'panchayat' means an institution of self-government constituted under Article 243B of the Constitution of India for rural areas. Article 243B stipulates that there shall be constituted in every state, panchayats at village, intermediate and district levels.
} 
achieved through a constitutional shift known as the Constitution (73 ${ }^{\text {rd }}$ Amendment) Act 1992 which definitively established decentralisation, mandating 24 states to constitute three levels of panchayats in rural areas and assign functions to them. It specified many facets of decentralised governance, including: direct elections to all levels of panchayats, a five-year term of office, reserved seats for women and minority communities, and devolution of funds, functions and functionaries to gram panchayats (GPs). The Eleventh Schedule (Article 243G) added as part of this amendment elaborated on the 29 functions that were devolved to GPs. These include, among others, crucial development sectors such as agriculture, health, education, social justice, water and sanitation. States like Karnataka, which will be the focus of this study, have devolved all 29 functions to the level of the GP (The Constitution of India; Centre for Policy Research 2014).

However, despite the constitutional mandate, it became apparent that GPs remained weak organisations - structurally and systemically - and were unable to discharge their responsibilities. "It must be recognised that the local governance system will not provide answers to local problems and development imperatives unless such a system is responsive to these problems, effective and efficient in its reach" (Aziz 2000, p. 3521).

\section{Statement of objectives}

The objective of this paper is to explore how organisation development principles can strengthen the functioning of GPs in India.

\section{Methods adopted in the paper}

\section{Approach}

A review of secondary literature reveals a dearth of work pertaining to organisation development (OD) in the context of local governance. This paper examines the application of OD principles to local governments in India, through an innovative framework termed the Gram Panchayat Organisation Development (GPOD) framework. It seeks to create a body of bottom-up evidence that will expand the literature related to OD in governance and encourage further research on the subject.

The authors suggest that development practitioners might gain from applying OD principles to GPs, as would commonly be done in a private sector or public sector enterprise, to ensure an integrated approach to organisational strengthening within local governments.

The paper discusses and critiques empirical findings from an action research project which aimed to embed the GPOD framework in two GPs in Karnataka for 2011-2013. Beyond the project, the GPs continued to implement the framework till the end of their electoral terms in 2015. 


\section{Findings}

The findings of the study reveal not only the benefits of applying OD principles in GPs, but also a need to simultaneously differentiate and integrate different organisational components (vision, organisation structure, incentives, resources, action plans) to maximise overall effectiveness. However, the authors acknowledge that the scale of the study (two panchayats) is an obvious limitation, suggesting the need for future research that replicates the current study in other panchayats before findings can be generalised.

\section{Context of organisation development in local governance}

The GPOD project traces its roots to ASHWAS (A Survey of Household Water and Sanitation), a study conducted by Arghyam in the period 2008-09 and covering 172 GPs across 28 rural districts of Karnataka. The results of ASHWAS were disseminated in the form of GP-specific reports to impacted rural communities and it was hoped that these GPs would then act as strong catalysts for action planning and implementation to address various water and sanitation issues emerging from ASHWAS. However, the local reality was starkly different. ASHWAS dissemination meetings showed that most GPs did not have the capacity to internalise the issues raised and take action (Srivastava 2014b).

It was the realisation that GPs were failing to undertake their mandated functions and duties that triggered the authors' interest in applying organisational change management principles and techniques to these village bodies with the objective of improving their efficiency. This is in keeping with other researchers' findings that planned change is usually spurred by the failure of organisations to evolve to meet changing requirements, or the inability of people to embrace continuous change (Weick and Quinn 1999; Greiner 1998).

In setting OD's theoretical context as it relates to local governance, however, it is important to note a few primary challenges. Firstly, there is a dearth of public administration literature pertaining to OD in the context of local governance. As Fernandez and Rainey (2006) note, research and theory related to organisation change and allied topics is more likely to find space in journals specialising in general management than those focusing on public administration (Fernandez and Rainey 2006). Secondly, OD literature has largely limited itself to distinguishing between public and private organisations, with a widely acknowledged failure to address the sub-dimensions that distinguish individual organisations within the public and private spheres (Perry and Rainey 1988; Austin and Bartunek 2003).

Local governments, however, need to be regarded as a separate category of public entity, since they operate in distinct circumstances and conduct their affairs differently from state and federal agencies, argue Gabris and Golembiewski (1996) in their paper 'The Practical Application of Organization Development to Local Governments', adding that the design of OD interventions should be sensitive to such nuances: 
...another salient area of difference that is not necessarily captured by the public versus private dichotomy involves differences between local government as a special form of public organisation in contrast to other forms associated with federal and state governments. The difference between how local governments conduct business and the environment in which they struggle to survive, in contrast to state and federal agencies, may be just as great and salient as public versus private sector variants. Yet the former source of difference is rarely considered (Gabris and Golembiewski 1996, pp. 72-73).

A review of change management literature shows that there is a well-established rationale for applying OD to local governance. Local governments are self-contained units and thus likely to offer more scope for systemic overhaul. Their small size facilitates appropriate diagnosis, data management and interventions with potential for meaningful change to be realised. Unlike other change management strategies, OD has humanistic value orientations that allow members within the organisation to grow and realise their individual potential as part of the change process towards achieving organisational efficiency. Additionally, given the proximity of local governments to their citizens, they are believed to display a higher adaptability to change (Burke 1987, cited in Sminia and van Nistelrooij 2010; Cobb and Margulies 1981; Gabris and Golembiewski 1996; Schneider et al. 1996; Srivastava 2014a).

For these reasons, this paper starts from the premise that GPs, just like corporate bodies, nongovernmental organisations (NGOs) and trusts, need to be treated as a distinct category of organisation, which requires a holistic and tailored approach in order to fix their dysfunctionalities. Change cannot be achieved through ad-hoc measures targeted at stand-alone components; rather it requires a systemic approach.

OD has been variously defined and described in change management literature, but theorists often take as a starting point Kurt Lewin's three stages of change as fundamental to OD. Simply put, these stages are 'unfreeze', 'change' and 'refreeze':

From the perspective of organisational development, change is a set of behavioural science-based theories, values, strategies and techniques aimed at the planned change of the organisational work setting for the purpose of enhancing individual development and improving organisational performance, through the alteration of organisational members' on-the-job behaviour (Porras and Robertson 1992, cited in Weick and Quinn 1999, p. 363).

For the construction of their GPOD framework, the authors were inspired by the Delores Ambrose model (1987), with its premise that change is successful only when all the organisational components - vision, skills, incentives, resources, action plan and results - are in alignment. Interventions introduced to target one-off components such as decision-making processes, planning or incentives will not result in effective change (Schneider et al. 1996; Srivastava 2014a).

Most theorists believe that the sustainability of OD interventions ultimately hinges on organisation members themselves and their equal and active participation in the change process all the way through, from decision-making to implementation. While interventions may be facilitated by outsiders, members cannot be dependent on external stakeholders, as the success of a change process is ultimately 
determined by whether organisation members themselves take ownership of it. Thus OD encourages an environment of openness, mutual learning and inclusiveness (Cobb and Margulies 1981; Gabris and Golembiewski 1996; Scott-Villiers 2002).

Figure 1: The Delores Ambrose model of managing complex change

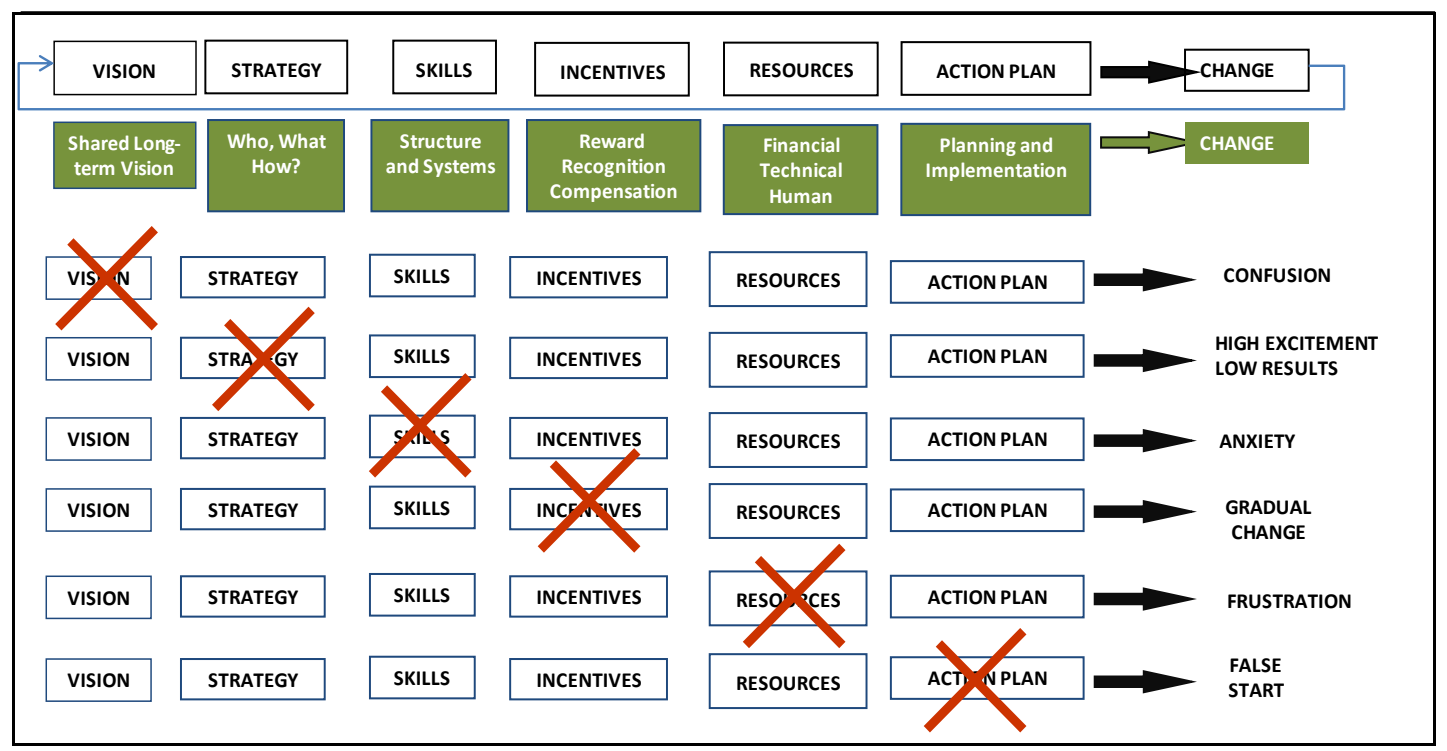

Source: Ambrose (1987)

As Schneider, Brief and Guzzo (1986) point out in their paper 'Creating a climate and culture for sustainable organisation change': "Organisations as we know them are the people in them; if the people do not change, there is no organisational change" (Schneider et al. 1996, p. 7).

\section{Methodology: the GPOD framework}

Conceptual work on the GPOD framework began in 2011 with an exploratory study to ascertain the existing status of GPs in India and map the scope of existing capacity-building programmes. Preliminary primary research was undertaken through consultations with stakeholders familiar with rural governance in India, while data mining provided a secondary source. ${ }^{2}$

It was found that existing capacity-building efforts could be broadly divided into four types: leadership programmes for the adhyaksha (president) and other elected members; training initiated by government agencies and NGOs for knowledge-building on specific government programmes; capacity-building training as part of targeted programmes such as the Backward Region Grant Funds; and training

\footnotetext{
2 Primary consultations were undertaken with key informants including: a Member, Planning Commission; the Secretary for Rural Development and Panchayati Raj Department, Government of Karnataka; an IAS officer and co-founder of Avantika Foundation; an eminent retiree who was a member of several bodies such as the Administrative Reforms Commission, Institute of Rural Management, National Dairy Development Board etc.; a trustee of Trust For Village Self Governance, and organisations including Abdul Nazir Sab State Institute of Rural Development, Mysuru, Gram Panchayat Nademavamapura, Gram Panchayat Vasana, Myrada, Department of Watershed, Government of Karnataka, Arghyam and Gram Panchayats of Hebbali. A consultation was also held at the Planning Commission on 24 November 2010. Secondary data was gathered from an analysis of 10 strong and weak gram panchayats conducted by communications, development and learning, ASHWAS (2008-09), Promoting Effective Water Management Policies and Practices, ADB \& UNESCAP, the Karnataka Panchayat Raj Act, 1993, and other government documents (Srivastava 2014b).
} 
undertaken by the Institutes of Rural Development which are present in every state. The researchers' analysis indicated that training for elected representatives consisted largely of classroom-based sessions and failed to provide GP members with the skills, information or knowhow required to handle the enormous responsibility and functions devolved to them. Moreover, even in cases where training programmes were effective, they imparted knowledge and skills which recipients could not use due to lack of role clarity and/or incentives. It was also found that training often over- or under-emphasised certain components of GPs and thus neglected a systemic approach. GPs were also found to suffer from a lack of control over their finances, the capture of decision-making by either politically-motivated individuals or government-appointed executive staff, and the exploitation of their resources by a select few. Because of a lack of a strong identity and reasonable incentives, members were often rather uninterested in the functioning of their panchayat. Given this context, there was little faith in either the abilities or the motivations of panchayats, and both government and NGOs often bypassed these elected bodies and created parallel bodies to deliver core services to rural citizens (Srivastava 2014b).

It was against this backdrop that GPOD was conceived. GPOD was envisaged as a framework which would strengthen GPs to enable them, both systemically and structurally, to undertake their mandated duties. Based on OD principles, the GPOD framework aimed to strengthen GPs organisationally and bring about convergence of panchayats and government agencies in order to improve governance and service delivery for rural citizens.

It was decided to develop the framework using action research methodology. Action research, also known as participatory research, collaborative inquiry or emancipator research, is basically 'learning by doing' or participating in the change process itself (O'Brien 2001; Scott-Villiers 2002). The term was first used by Kurt Lewin in his paper 'Action Research and Minority Problems', in which he described research in the social research context as 'social management' or 'social engineering'. In other words, he believed on-the-ground action, research and training were interdependent. Just like pure science, action research is suitable for conceptual problems that can be theoretically or statistically analysed, and requires fact-finding in descriptive terms and field experiments to test social change (Lewin 1946).

Action research for the GPOD project was situated in two GPs in the state of Karnataka in south India - Oorkunte Mittur in Kolar District and Dibburhalli in Chikkaballapur district, together covering 32 villages and reaching a population of 15,220 citizens. The project was incubated in January 2011 in Arghyam Foundation and was housed in Avantika Foundation from April 2014 till March 2015. In the action research phase, the authors worked with two different types of GPs to enhance their learning. For example, at Oorkunte Mittur GP all members were newly elected, whereas Dibburhalli was more politically active and had three experienced members who were in their second or third term. 
Table 1: Demographic profile of gram panchayats

\begin{tabular}{|l|c|c|}
\hline Name of gram panchayat & Number of villages/wards covered & Population \\
\hline Oorkunte Mittur, Mulbagal Taluka, Kolar District & 13 & 7,482 \\
\hline $\begin{array}{l}\text { Dibburhalli, Sidleghatta Taluka, Chikkaballapur } \\
\text { District }\end{array}$ & 19 & 7,738 \\
\hline
\end{tabular}

Source: Srivastava (2014a)

In keeping with the core principles of OD, elected GP representatives were primary stakeholders in the change process and were involved in designing the GPOD, shaping the framework with their own experiences and learnings. GP members also played a crucial role in encouraging the entire village body to participate in the action research. This sense of equal partnership carried through to implementation of GPOD as well, with every step ratified as a GP resolution, as per the requirements of the law.

Given this premise, selection of the two GPs studied was a stringent process, requiring the GP to be willing to actively engage in seeking and developing solutions. Twelve GPs were shortlisted and evaluated on two four-point objective rating scales, comprising both qualitative and quantitative parameters: Scale I evaluated GP interest in the project, and relationship with a local NGO and Scale II evaluated the processes and performance of the GP, and the competencies of its members.

Scale I was important because members' interest was crucial to a successful change process, while Scale II was important in evaluating the GPs' interest in good governance - the premise being that initial good results reflected members' intentions to work towards sustainable change. It was expected that the GPs would show marked improvement on Scale II in the course of the action research phase.

Inspired by the Delores Ambrose model, the GPOD framework is a step-by-step framework for planned change in the village bodies (see Figure 2). It is important to note that, rather than following the Ambrose model exactly, the GPOD framework draws upon its principles - i.e. the need to simultaneously differentiate and integrate different components of an organisation - in this context the GP. Differentiation helps focus on individual systems and structures, while integration aligns different components of the organisation to deliver its overall mandate. This approach also ensures flexibility for the framework to change depending on the local government organisation and its needs.

While Figure 2 shows GPOD as a linear step-by-step process, the authors emphasise the need to strengthen individual components within organisations and the links between them. The following sections describe each of these components and their role in organisation-building in GPs. 
Figure 2: Overview of GP organisation development process

\begin{tabular}{|c|c|c|}
\hline A. PREPARATION & $\begin{array}{l}\text { B. ORGANISATION DIAGNOSIS \& } \\
\text { DESIGN }\end{array}$ & $\begin{array}{c}\text { C. HANDHOLDING } \\
\text { IMPLEMENTATION \& NEXT STEPS }\end{array}$ \\
\hline a & $\mathrm{v}$ & $\begin{array}{l}\text { C. Planning and Review } \\
\text { Processes }\end{array}$ \\
\hline \multirow{16}{*}{$\begin{array}{c}\text { A. Preparation } \\
\text { * Time taken: } 3 \text { months } \\
\text { * Activities: preparation of } \\
\text { project scope, structure, plans } \\
\text { \& budgets; mapping the } \\
\text { project structure; \& selection } \\
\text { of GPs } \\
\text { * Key outputs: project } \\
\text { document; MoUs with all } \\
\text { partners; \& tripartite MoU } \\
\text { between Arghyam, NGO \& GP }\end{array}$} & B1. Vision \& Mission & \multirow{11}{*}{$\begin{array}{c}\text { C. Planning and Review } \\
\text { Processes } \\
\text { * Time taken: planning } \\
\text { exercise after requisite inputs: } \\
2 \text { months; review: ongoing } \\
\text { * Activities: } \\
\text { - Planning: developing } \\
\text { requisite inputs; collating } \\
\text { information on programmes \& } \\
\text { schemes; GP-MIS \& } \\
\text { knowledge partners; arriving } \\
\text { at long-term outcomes \& } \\
\text { metrics with GP; developing } \\
\text { annual plan \& budget; \& } \\
\text { finalising annual plan \& } \\
\text { budget } \\
\text { - Review: GP review meetings; } \\
\text { quarterly meeting with } \\
\text { standing committees \& citizen } \\
\text { forums } \\
\text { * Key outputs: }\end{array}$} \\
\hline & \multirow{2}{*}{$\begin{array}{l}\text { * Activities: training resource } \\
\text { persons; finalising GP-specific } \\
\text { methodologies; GP orientation; \& } \\
\text { vision \& mission processes } \\
\text { * Key outputs: vision \& mission } \\
\text { statements; resolution passed by } \\
\text { Gram Sabha; \& ward-wise list of } \\
\text { quick wins }\end{array}$} & \\
\hline & & \\
\hline & \multirow{2}{*}{$\begin{array}{c}\text { * Key outputs: vision \& mission } \\
\text { statements; resolution passed by } \\
\text { Gram Sabha; \& ward-wise list of } \\
\text { quick wins }\end{array}$} & \\
\hline & & \\
\hline & 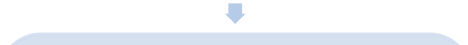 & \\
\hline & B2. Process Mapping & \\
\hline & *Time taken: 3 months & \\
\hline & & \\
\hline & $\begin{array}{l}\text { processes; process mapping } \\
\text { workshops in each GP; validation } \\
\text { \& consolidation }\end{array}$ & \\
\hline & $\begin{array}{c}* \text { Key outputs: process maps of } 17 \\
\text { processes }\end{array}$ & \\
\hline & $\sqrt{2}$ & - Planning: function-wise \\
\hline & B3. Organisation Structure & information on government \\
\hline & $\begin{array}{l}\text { * Activities: training resource } \\
\text { persons; assessing present GP } \\
\text { structure; finalising recommended } \\
\text { GP structure; \& evolving process \& } \\
\text { criteria for selection of GP heads }\end{array}$ & $\begin{array}{l}\text { funds; GP-MIS; roles \& plans } \\
\text { of knowledge partners; } \\
\text { function-wise outcome and } \\
\text { metrics of the GP; annual plan } \\
\text { \& budget in MIS format \& }\end{array}$ \\
\hline & ${ }^{*}$ Key outputs: drivers for GP & approved plans by gram sabha \\
\hline & $\begin{array}{l}\text { structure design; recommended GP } \\
\text { structure; \& differential } \\
\text { compensation system for GP Heads }\end{array}$ & $\begin{array}{l}\text { - Review: monthly update of } \\
\text { MIS; \& modalities of } \\
\text { stregthening standing } \\
\text { committees \& citizen forums }\end{array}$ \\
\hline
\end{tabular}

Source: Srivastava (2014a)

\section{Vision and mission}

GP vision and mission development is the cornerstone of OD exercises, as it guides future decisionmaking. Vision can be defined as an articulation of the desired state of an organisation, while mission elaborates upon the purpose of an organisation and the mechanism by which its vision would be achieved.

In the context of GPs in India, the identity of the GP as a local self-government is weak, primarily because the state treats GPs as extended arms for the implementation of its programmes and schemes. This situation, coupled with low awareness of their role among elected members, leads to GPs not functioning as governments. The goal of developing the GP vision and mission is twofold: to highlight 
the identity of the GP as a self-governing unit, and to build a sense of association with and ownership of the GP among elected members and staff. Within this context, the GPOD visioning process was designed to help participants articulate their dreams as well as consolidate their shared values for the institution. To achieve this, a range of participatory rural appraisal techniques such as transect walks, social and resource mapping, wealth ranking and focus group discussions were used. The authors chose these participatory tools because they were tools that NGOs and the community were familiar with, and they were also easier to administer than questionnaires and other data collection techniques.

Figure 3: Illustration of vision and mission statements by Oorkunte Mittur gram panchayat

Overall sustainable development through transparent and good governance
Our Values
Teamwork, Equality, Trust, Citizen Participation, Commitment, and Service Orientation
Mission
Our key stakeholders are our citizens. We will constantly strive to understand their needs and aims towards
improvement in governance and delivery of services
$\begin{gathered}\text { To work towards this, we will strengthen the GP both physically and institutionally. The GP office will be a } \\ \text { citizen-friendly and beautiful place with availability of basic facilities for visiting citizens, office bearers and } \\ \text { members }\end{gathered}$
We will display unity and decorum among members and ensure transparency and accountability in our
functioning. We will focus on financial strengthening through setting appropriate tariff rates and ensuring
collection

\section{Process mapping}

Process mapping is an effective diagnostic tool to analyse the functioning of an organisation. GPs in India have been given a huge mandate for delivering services to citizens. However, there is a lack of clarity on both how these services are to be delivered and the roles of different stakeholders. The Government of India is undertaking an activity mapping exercise to demarcate roles among three layers of panchayat raj institutions (PRIs). However, further delineation of activities at the panchayat level is mostly non-existent or - at best - present in national programme guidelines which are not always locally relevant, leading to ad-hoc measures and firefighting to resolve issues at local level. The authors used process mapping to assess the 'as-is' state of functioning of the panchayats under study. This involved sequentially listing all activities performed while delivering key processes, while simultaneously demarcating the roles of different stakeholders using an $\mathrm{RACI}^{3}$ matrix. The GP vision and mission established above provided the list of functions and processes in which the GP wanted to improve its delivery.

\footnotetext{
${ }^{3} \mathrm{RACI}$ is an established OD tool used to identify and map stakeholders according to their responsibility (R), accountability (A), collaboration (C) and provision of information (I).
} 
Figure 4: Illustration of process map for supply of drinking water through pipelines, delineating activities and assigning them to different stakeholders using a RACI matrix

\begin{tabular}{|c|c|c|c|c|c|c|c|c|c|c|c|c|c|c|c|c|c|c|c|c|}
\hline & & & & 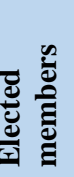 & & 尝 & 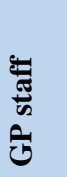 & & $\begin{array}{c}\tilde{\Xi} \\
\vdots \\
\dot{\Xi} \\
\dot{\omega}\end{array}$ & & $\frac{a}{4}$ & & 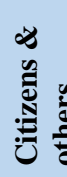 & & & 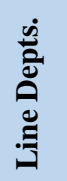 & & & & \\
\hline$\sum_{i}^{0}$ & $\begin{array}{l}\text { Name of the } \\
\text { Process \& } \\
\text { Related Roles } \\
\text { Type of } \\
\text { Function } \\
\text { R- } \\
\text { Responsibility } \\
\text { A- } \\
\text { Accountability } \\
\text { C- } \\
\text { Collaboration } \\
\text { I-Providing } \\
\text { Information }\end{array}$ & 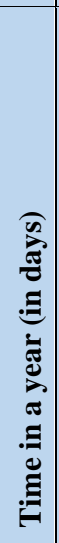 & 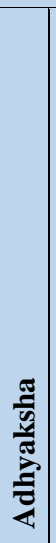 & 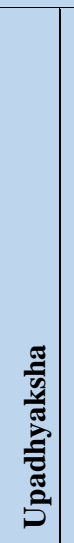 & 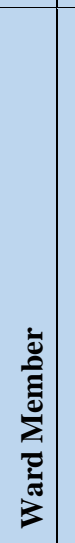 & 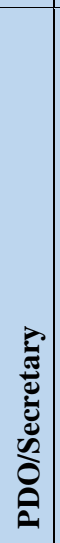 & 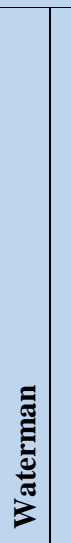 & 离 & 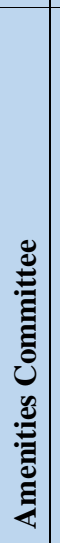 & 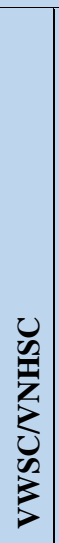 & 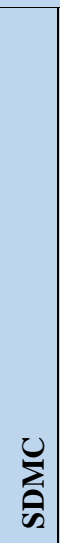 & 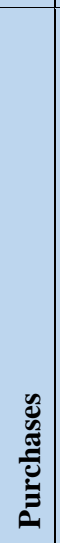 & : & 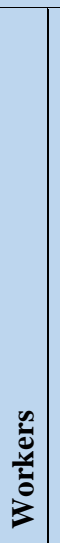 & 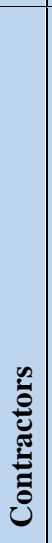 & 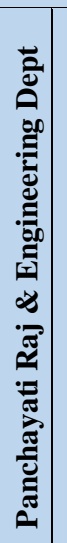 & 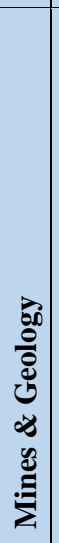 & $\begin{array}{l}\hat{\mathbf{N}} \\
\dot{z} \\
\hat{\sigma}\end{array}$ & $\stackrel{0}{\vec{E}}$ & $\begin{array}{l}\text { Issues } \\
\text { which } \\
\text { need to } \\
\text { be dealt } \\
\text { with in } \\
\text { the GP }\end{array}$ \\
\hline & $\begin{array}{l}\text { Drinking water } \\
\text { through piped } \\
\text { water supply }\end{array}$ & & & & & & & & & & & & & & & & & & & $\begin{array}{l}\text { Non- } \\
\text { clarity on } \\
\text { R \& A }\end{array}$ \\
\hline 1. & $\begin{array}{l}\text { Get report on } \\
\text { 'survey of } \\
\text { quantity of } \\
\text { water' available }\end{array}$ & & $\mathbf{R}$ & & & $\mathbf{A}$ & & & & & & & & & & & $\mathbf{I}$ & & & $\begin{array}{l}\text {-Delay in } \\
\text { response } \\
\text { from } \\
\text { depts. } \\
\text { - PDO/ } \\
\text { ward } \\
\text { member } \\
\text { has to }\end{array}$ \\
\hline 2. & $\begin{array}{l}\text { Quality } \\
\text { Assessment \& } \\
\text { Monitoring } \\
\text { Report }\end{array}$ & 8 & $\mathbf{R}$ & $\mathbf{R}$ & & $\mathbf{A}$ & & & & & & & I & & C & I & & & & $\begin{array}{l}\text { make 2-3 } \\
\text { trips as } \\
\text { official } \\
\text { may not } \\
\text { be } \\
\text { available } \\
\text { - MLA } \\
\text { support } \\
\text { might } \\
\text { help } \\
\text { expedite } \\
\text { process }\end{array}$ \\
\hline
\end{tabular}

As an example (see Figure 4 above), the process of supplying drinking water through pipelines was mapped through discussions with panchayat members and a sample of citizens, and reviewed by experienced peers from other panchayats. The process mapping exercise itself helped articulate many issues and highlight them through the RACI matrix.

The exercise helped the authors identify operational, structural and policy-related strengths that facilitate effective delivery of citizen services, as well as issues that hinder it. Examples include: the need to arrange funds for petty purchases to deal with minor repairs in the panchayat (operational); lack of clarity on the respective roles of the GP and government departments, leading to the GP not knowing 
what to expect from these agencies (structural); and the inadequate incentives (monetary or nonmonetary) for elected members (policy). The participatory approach adopted towards fixing processes significantly improved awareness of the issues among elected members, who were also able to see how significant improvements could be achieved at panchayat level, thereby promoting ownership (Srivastava 2014a).

The action research project mapped 12 key processes of GPs, which had been identified by elected representatives of individual panchayats as priority areas during the vision and mission development process. These processes included water and sanitation, nutrition and agriculture, among others, and the process maps were subsequently overlaid with performance measures.

Some of the key insights from the process mapping exercise are listed below:

- A GP member is or needs to be involved in myriad activities in the GP, for most of which $\mathrm{s} / \mathrm{he}$ is held either accountable, or at least responsible, by the citizens

- While expectations of what GPs should provide are laid down, there is no formal agreement between GPs and other government agencies which stipulate specific deliverables by the latter

- Different GPs follow different processes for service delivery, which are primarily based on their own knowledge and experience. Most of their time, however, is spent fighting crises

- Due to a lack of readily available funds, GP members often spend their own money on expenses such as replacing street lights or broken taps, and may not be reimbursed until much later

- There are a number of issues specific to each process which need to be resolved. These include ambiguity regarding the official list of citizens living below the poverty line (BPL), flawed assessment processes to determine how many additional public taps are required, and the shortage of gramthana land (land which can be allocated for housing).

Although the resolution of operational issues was a lengthy process, as it was dependent on availability of funds and other resources, GPOD was able to address structural issues such as lack of an accountability mechanism and non-clarity of roles. This is further explained in the next section.

\section{Developing the panchayat organisation structure}

A well-defined structure is key to achieving organisational objectives. A structure comprises a formal allocation of roles with delineated functions for each, which is clear enough to be depicted on an organisational chart. As a local self-government body, a GP should ideally have well-defined roles for its members with clarity on interfaces with external stakeholders such as government departments and block and district panchayats. However, the present research project found the current organisational structure as mandated by the Karnataka Panchayat Raj Act 1993 to be inadequate, and that individual roles within the panchayat were unclear and confusing. 
The GP structure as defined under state law comprises an adhyaksha, upadhyaksha (panchayat vicepresident) and three standing committees responsible for different functions. Government departments are mandated to provide technical support to members and aid implementation of rural development programmes. The GP is accountable to mandated citizen bodies at village and panchayat levels (ward and gram sabhas respectively, as per Sections 3 and 3A, Karnataka Panchayat Raj Act). In Karnataka there are also some paid employees (paid either by the panchayat or by other government agencies) who have assigned responsibilities. The authority for approving expenditure and making decisions is shared between the adhyaksha and the key government employee, the panchayat development officer (PDO).

Elected representatives however, felt that the current structure was riddled with problems, which hindered the functioning of the GP as a local self-government. While the citizens held the elected members accountable for service delivery, the members did not feel empowered to perform and decide on key issues, due to a lack of knowledge and role clarity. The wards of weaker members suffered, as their representatives did not have a voice in the panchayat. The standing committees, which are theoretically accountable for specific functions and sectors, mostly exist on paper only. The adhyaksha and upadhyaksha are nominally the heads of different standing committees, but may not have the required expertise and knowledge to make them effective. The PDO, though in theory serving the panchayat, is its de facto head due to his/her higher education, training and links with the block and district panchayats. Moreover, the PDO's salary is paid by the block panchayat, thereby ensuring that his/her allegiance lies with higher level government agencies and not the GP. Consequently, the researchers found that decisions were opaque and usually made by the PDO/secretary or a few strong GP members who dominated the power structure, often side-lining other members. Operationally, due to a lack of well-defined systems, processes and structure, GPs' work often consisted of 'fire fighting' as they lurched from crisis to crisis.

An effective structure needed to utilise the potential of elected members, enable the panchayat to work closely with government departments and leverage their financial and technical resources, and distribute leadership so as to reduce chances of dominant member(s) usurping power. The structure also needed to deliver the GP's functions as per its constitutional mandate. Therefore, although the classic RACI matrix allocates accountability to a single individual, the researchers decided to add a new tier, comprising GP members with capabilities and inclinations focused on specific areas who would take ownerships of an individual portfolio of functions in addition to representing their ward. Elected members would effectively be portfolio heads, tasked with executive responsibilities and accountable for all aspects of the functions assigned to them, from pre-planning to implementation.

When these concepts were shared with panchayat members, they suggested an alignment with the existing standing committee structure to ensure better acceptance of the augmented structure. Thus the portfolio head would be the executive head of the functions of existing standing committees, but 
signatory powers would remain with the adhyaksha, in line with existing policy. In addition to leveraging the potential of capable and motivated elected members, the new portfolio structure aligned the panchayats with government departments, which are delineated by sector, and also ensured distributed leadership within each panchayat.

In keeping with OD principles, however, this paper acknowledges that every panchayat has a unique character and its structure should ideally be designed according to the priorities of its members. The GPOD framework merely lays down the principles of design.

Figure 5(a): GP structure as mandated by the Karnataka Panchayat Raj Act 1993

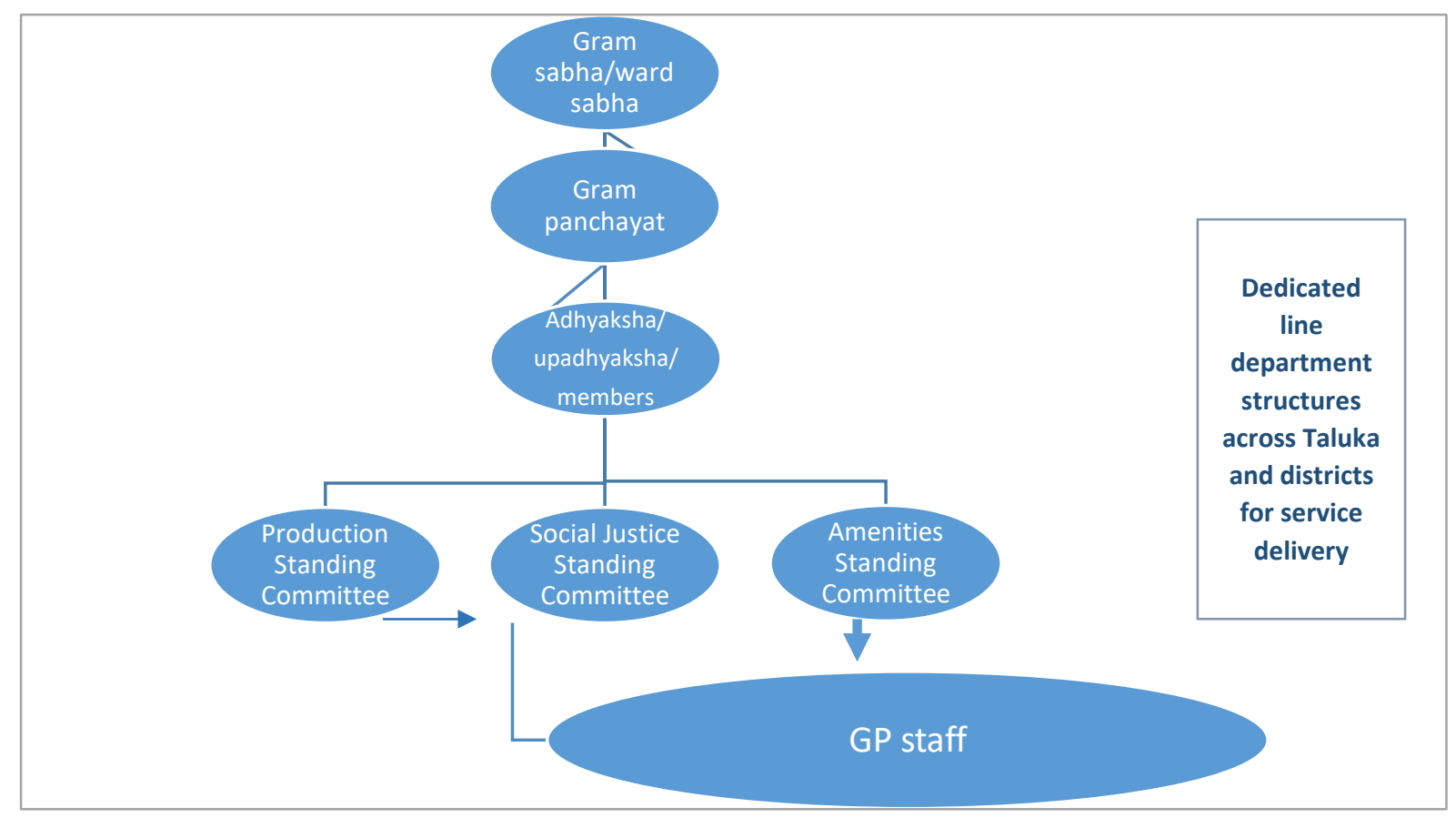

Source: Srivastava (2014a)

As the structure began to work, most portfolio heads thrived in their newly acquired roles and were able to use their capabilities to bring about substantive changes in the panchayat. A member widely acknowledged as a good farmer was selected as head of production, taking on responsibility for functions such as agriculture and animal husbandry, National Rural Employment Guarantee Act (NREGA), revenue generation and greening the village. The portfolio heads were accountable for the delivery of processes/functions assigned to them, including pre-planning, planning and implementation, and worked closely with the relevant government department, the statutory standing committees and statutory citizen sub-committees. The relevant GP staff reported to these function/process owners, and line departments also coordinated with them. Accountability (and leadership) was thus distributed among the GP members identified as heads. One unexpected but welcome consequence was that there was greater transparency in panchayat functioning. 
Figure 5(b): GP augmented structure as envisaged in the GPOD framework

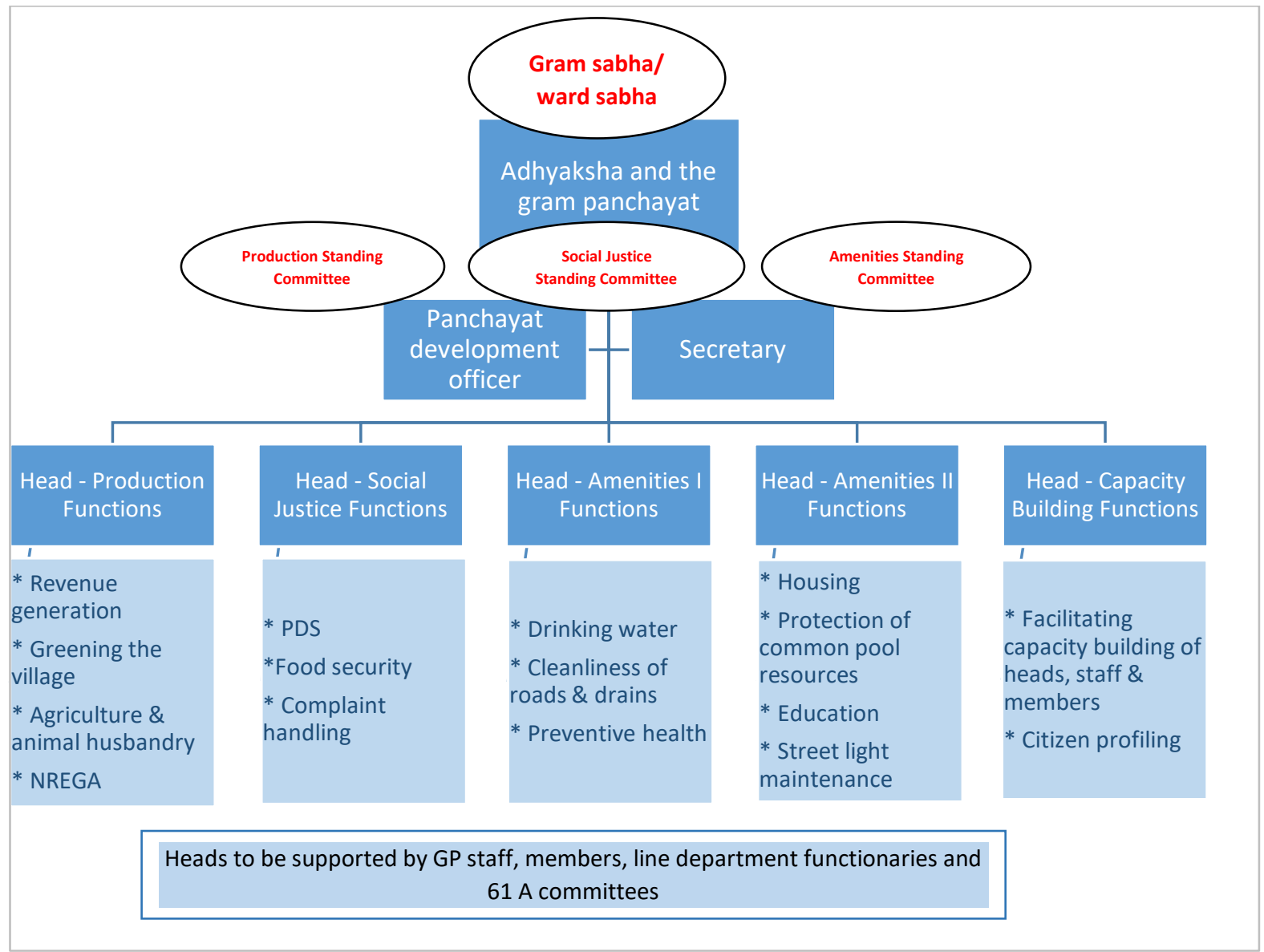

Source: Srivastava (2014a)

\section{Perspective and annual planning, implementation}

GP planning guidance is provided by the Karnataka Panchayat Raj Act, and also in the Planning Commission of India's Manual for Integrated District Planning (Planning Commission 2008). This guidance stresses that issues should be identified by ward and gram sabhas and solutions proposed by the GP standing committees and/or working groups; followed by an iterative process of preparation and ratification of draft plans by standing committees and the gram sabha before finalisation. However, few GPs put these guidelines into practice. The PDO or panchayat secretary often draws up the annual plan without consulting elected representatives. Moreover, the panchayat has a minimal role in implementing plans, which lies in the purview of the line departments. The GP thus loses control of its plans. At worst, plans may remain on paper; at best they may be implemented but without necessary corrective measures based on changing priorities etc.

In this context, lack of capability of panchayat members, in relation to both functional knowledge and knowledge of how government systems function, hinders the GP in preparing or executing effective plans. The authors believe GPs need to play a key role in implementation as well as planning, as this enables the local community to harness its traditional wisdom while simultaneously accessing modern techniques. Moreover, an iterative cycle of 'Plan-Do-Check-Act' (the Deming PDCA cycle), 
strengthens the planning and implementation process and converts it into a continuous improvement process (Deming n.d.). Within the augmented GP organisation structure devised by this research, portfolio heads took responsibility for discussing citizen needs during ward sabhas to prioritise activities and draw up a draft plan, which was then presented to the GP and subsequently the gram sabha for approval. As the portfolio heads possess the relevant capacities, and also take ownership of planning and implementation, the discussion during both ward sabhas and the gram sabha is geared towards problem-solving rather than hearing grievances, which have to be reported upwards to be resolved.

Acknowledging the technicalities and complexities of the planning process, the authors initiated planning as a simple process in the first year, and fine-tuned the method in the second year. This allowed panchayat members to develop their strategic skills. Over time, the process in the two action research GPs has significantly evolved. In the first year, planning focused only on activities which did not require funds or for which panchayats could raise their own funds. In the second year, planning acquired more nuances, encompassing activities with three different sources of funding: a range of government schemes, government sub-committees and panchayat own revenue. A GP-specific Management Information System (MIS) was also subsequently developed to track plans against their implementation on a monthly basis.

The GPOD framework as established is inherently self-sustaining. Rather than creating parallel structures to deliver services at the grassroots when GP structures have failed, it focuses on strengthening GPs, which are constitutionally mandated to function as local bodies within the current legal framework. Moreover, elections to panchayats are held every five years, ensuring a democratic mandate for those people who will take up defined roles. The challenge is to continuously develop solutions and systems which will provide and sustain an enabling environment for elected members to discharge their functions.

\section{Findings from GPOD implementation and critical insights}

The GPOD action research spanned a two-year period 2011-2013, but the two GPs under study continued to implement the GPOD framework until the end of their electoral term in May 2015.

The GPOD project is a step towards shifting perceptions of local government bodies in India. Rather than being perceived and treated as 'last tier' implementation arms of the government, panchayats have to build their capabilities as strong and autonomous local governments. These institutions can then demand intergovernmental equality and negotiate their rightful authority to address issues affecting rural citizens. The GPOD framework stresses the need for simultaneously differentiating and integrating different components of the GP organisation. Recognising this approach, the central government sanctioned a scale up of the concept as the country's first Innovation Project under the Rajiv Gandhi Panchayat Sashaktikaran Abhiyan (Village Council Strengthening Scheme). Accordingly, the Ministry 
of Panchayati Raj, the Government of India and the Government of Karnataka have partnered with the Avantika Foundation to implement the GPOD in an entire administrative block of the state. The project spans 30 GPs (covering 389 village and 2.02 lakh citizens) in Mulbagal taluka of the Kolar district, Karnataka for a two-year period from January 2015 to December 2016 and paves the way for future scale-up through the government machinery. Avantika Foundation along with the state government's Abdul Nazir Sab State Institute of Rural Development is concurrently developing a curriculum for the replication of the GPOD to other GPs in the state and beyond. The curriculum will be available in Kannada and English and suitable for translation into regional languages to facilitate knowledge sharing. Fourteen other GPs in Kolar and Chikkaballapur districts, Karnataka have also come forward and committed to work with the framework with support from regional NGOs.

The authors envisage the principles of GPOD as replicable and scalable and we acknowledge that impact evaluation is an important aspect of this. Since the action research was conducted as a pilot study we relied on a basic pre-post test design as a methodology for impact evaluation. We acknowledge that this methodology is open to research critique over its validity in establishing a causal relationship between the intervention and any shift in governance and service delivery, due to the lack of a control group. As progression is made from pilot to scale, the authors are in the process of exploring the potential of quasi-experimental methods and more rigorous random evaluation techniques to further validate the impact of the GPOD.

\section{Impact of GPOD}

The pre-post test design of this research involved the construction of an elaborate baseline for both the GPs under study. This was an exhaustive exercise in itself as data is scarcely available at the level of the GP, and information that is available is rarely in formats that are amenable to analysis. The Second Administrative Reforms Commission had suggested that development of indicators itself could be a useful capacity-building exercise for local governments, which was corroborated in our evaluation. Construction of the baseline was largely a participatory monitoring and evaluation exercise which involved multiple stakeholders in the evaluation process. Designated panchayat heads collected data for functions that fell under their portfolios and were responsible for tracking their progress on a monthly basis (Second Administrative Reforms Commission 2007)

The baseline covered 51 indicators at the meta-level of the GP across 13 crucial developmental sectors such as agriculture and animal husbandry, primary and secondary education, drinking water, sanitation, and housing among others. The sectors were aligned with the functions of GPs in order to capture impact of the GPOD intervention. A rigorous GP-MIS was then put into place to facilitate month-on-month tracking of this data. 
Table 2: Illustration of GP-MIS

\begin{tabular}{|l|l|l|l|}
\hline Sector & Broad goals & Indicator & Source \\
\hline Sanitation & Increase in toilet & $\begin{array}{l}\text { 1. Number of toilets constructed } \\
\text { 2. Number of information, education and } \\
\text { communication activities for spreading } \\
\text { information on the benefits of toilet } \\
\text { utilisation }\end{array}$ & $\begin{array}{l}\text { Gram panchayat records } \\
\text { from Nirmal Bharat } \\
\text { Abhiyan (toilet } \\
\text { construction scheme) }\end{array}$ \\
\hline
\end{tabular}

The above Table 2 shows the mechanism by which the baseline captured data related to sanitation. Sanitation is one of the 29 essential functions that have been devolved to the panchayat as per the Eleventh Schedule of the Constitution (The Government of India 1992). The broad goal of the panchayat is to improve the availability and usage of toilets, and this was operationalised through the Head Amenities I who oversaw sanitation as a function. He/she also played a crucial role in activation of the sub-committee formed by the government department responsible for drinking water and sanitation - Village Water and Sanitation Committee (VWSC) - which has the mandate to oversee operations and maintenance as well as fixing and collection of water tariffs. The baseline helped gather data on indicators such as the number of toilets in a current year as well as number of awareness initiatives on the usage of toilets. Indicators tracked and reviewed on a monthly basis helped capture the shift in toilet constructions, as well as usage. The source column indicates the source from which data was collected.

A pre-post analysis thus helped highlight the impact of a stronger GP. The systemic approach taken towards building the organisation capacity of the two GPs under study resulted in improvements in governance (systemic shifts) as well as service delivery.

\section{Systemic outputs realised:}

- For the past three years, Oorkunte Mittur and Dibburhalli GPs have annual plans and budgets in place and a clear accountability structure for their elected representatives.

- Mandated citizen committees such as the VWSC, Bal Vikas Samiti (Child Welfare Committee), School Development and Monitoring Committee, which were previously defunct, have been activated. Meetings were regularly held ensuring active citizen participation in key functions such as child development, nutrition and schooling.

- Citizen participation in mandated ward sabhas and gram sabhas increased.

All these processes, structures, annual plans and the implementation status of the two GPs which were instituted as part of the GPOD have been rigorously documented and details handed over by elected representatives to the panchayat office to help the newly elected body refer to historical data, as well as to take forward the portfolio-wise planning and implementation process. 
Tangible service delivery improvements for citizens were captured by the GP-MIS and were as follows:

- Diburhalli GP was ahead of all blocks in the Chikkaballapur district in achieving its targets against the plan as well as creation of assets under the National Rural Employment Guarantee Scheme (NREGA) in 2013-14.

- Oorkunte Mittur had the highest coverage of individual toilets in the Mulbagal block in 20132014.

- Ration (fair price) shops in both GPs started displaying details of ration supplied and daily distribution as per government norms.

- Systems were instituted wherein complaints about defective streetlights were fixed within a 48hour period.

- Both GPs ensured that nearly all ration shops displayed the monthly grain stock received and daily stock position for all commodities, as per government norms.

- Dibburhalli GP monitored collection of water tax to the tune of Rs 1 lakh versus a targeted Rs 1.75 lakh in 2014-2015.

- In Oorkunte Mittur, GP members facilitated the formation of nearly 10 raita samparka kootas (farmers groups) and ensured distribution of subsidised seeds to over 2,300 farmers in the last two years.

- Water testing for chemical contamination was conducted in 20 villages and 21 watermen trained on how to conduct these tests using water testing kits.

Given the centrality of organisation members to the GPOD process, the project also considers testimonials of GP members about the GPOD intervention as a means of impact assessment. Widely used as self-assessment tools, testimonials provide an opportunity to hear about the impact of a project through the voice of its principal stakeholders (Rietbergen-McCracken and Narayan 1998). This can be illustrated through the documented experience of GP members like Vijayamma. Many elected representatives like her admit to now having an increased sense of confidence in their abilities, clarity about their roles and responsibilities as elected representatives, and a sense of achievement regarding the efficient manner in which they were able to deliver essential services to citizens. By creating enabling environments and appropriate incentives for rural elected representatives, the GPOD project thus helped develop the social capital at the grassroots.

The authors recognise the impatience for tangible results, but we strongly believe that the GPOD framework will be sustainable over time only if we continue to invest in people, systems and processes in a continuous manner. The GPOD is not a static or stand-alone framework.

The process of developing, implementing and scaling up the GPOD framework has been a process of continuous learning fraught with several challenges. This paper offers critical insights in the belief that 
the GPOD framework should continuously imbibe positive and negative feedback loops to facilitate better replication in newer geographies and strive to convert its challenges into opportunities.

While this research has acknowledged the political economy variables in the GPOD framework, the scope of intervention could have been widened to engage with socio-political, cultural and heritage issues. Many of these variables such as caste divisions, gender inequality etc. proved to be a barrier to democratic functioning of the GP. Secondly, the introduction of the portfolio-based structure in the GP skewed our efforts towards elected representatives who took on additional responsibilities of a portfolio. Feedback from members and citizens indicated that that this study should have dedicated more time and resources to other members of the GP as well. Thirdly, we recognised the need for effective fiscal decentralisation, but could not provide adequate focus on this area. Research on local government finances is required to analyse various sources of funds that accrue to a panchayat, both internally and externally, as a first step to determine the 'as-is' state of panchayat funds and subsequently understand the associated inefficiencies. Fourthly, the GPOD project could have also leveraged the process mapping exercise more effectively to create guidelines and develop manpower models. The mapping exercise also threw up many issues and possible solutions. Each re-engineered process could have been implemented in a more structured manner and further analysed and documented in greater detail and fed into further outputs such as operational guidelines for the GP, or manpower mapping of GPs. This data holds significant potential to inform policy in the long run.

There are some policies, which are not in our immediate control, the election process being the topmost on this list. We encountered our first election cycle at the GP level in June 2015 and were disappointed to note that many of the elected representatives in the action research panchayats were unable to recontest elections due to the seat being reserved for a different category. ${ }^{4}$ The other prevalent reason being the mounting, albeit illegal, electoral expenses involved. We recognise the need to engage with the election reform processes at the policy level in the long run in order to ensure more effective sustainability of our change efforts.

\section{Conclusion}

This paper reinforces the identity of the GP as a local self-government body. It illustrates the panchayat's innate potential and its ability to deliver beyond its constitutional mandate, if presented with an enabling environment and the appropriate incentives. It thus elaborates the use of OD principles to leverage this potential effectively.

This paper begins by providing an overview of democratic decentralisation with a specific focus on India. Through a thorough review of change management literature, it then lays down a contextual

\footnotetext{
${ }^{4}$ In the elections to the panchayati raj institutions, seats are reserved for a specific caste or gender, as a step towards affirmative action.
} 
framework for the application of organisation development to GPs. The basic premise is that GPs today seem to lack implementation skills to undertake the wide-ranging functions that have been devolved to them by law, and the shortfall can be attributed to their lack of organisational capacity.

The paper acknowledges the wide array of capacity-building efforts that have been applied to GPs, and reasons as to why these strategies have largely been ad-hoc and ineffective.

We argue that GPs just like corporate bodies, NGOs or trusts are organisations in their own right and the change process aimed at increasing their efficiency cannot address stand-alone components. Effective change in GPs requires a systemic approach addressing several components of the organisation, as well as recognising the potential of individually elected representatives towards achieving organisational efficiency of the GP as an institution.

The paper elaborates upon the methodology used to construct an innovative change management framework for local governments - the GPOD framework - through an action research undertaken in two GPs in Karnataka, India over a two-year period. The GPOD takes a participatory and systemic approach by undertaking vision and mission development with the GP, mapping key processes, devising appropriate accountability structures and incentives and handholding the panchayat towards effective implementation.

Through a pre- and post-design study, the paper then highlights demonstrable impact in development indicators in the two GPs where the GPOD intervention was introduced. Impact is illustrated both through systemic outputs and service delivery. The two GPs have laid down accountability structures, prepared three annual plans, activated defunct government-mandated committees and managed to attract more citizens to gram and ward sabhas. At a service delivery level, they have demonstrated marked improvements in crucial sectors such as sanitation, drinking water supply and education.

The paper acknowledges that the GPOD framework is designed to always remain a work-in-progress and critiques gaps that were identified in the GPOD methodology and implementation as it was being scaled up to other geographies. Suggestions have been offered to plug these lacunae.

\section{References}

Ambrose, D. (1987) Managing complex change. Pittsburgh: The Enterprise Group Ltd.

Austin, J.R. and Bartunek, J.M. (2003) Theories and practices of organizational development. In: Weiner, I.B. (ed) Handbook of psychology (pp. 309-332). Tampa, Florida: John Wiley and Sons, Inc. doi: https://doi.org/10.1002/0471264385.wei1213

Aziz, A. (2000) Democratic decentralisation: Experience of Karnataka. Economic and Political Weekly, 35 (39), $3521-3526$.

Bardhan, P. (2002) Decentralization of governance and development. The Journal of Economic Perspectives, 16 (4), 185-205. doi: https://doi.org/10.1257/089533002320951037

Census of India. (2011) Rural urban distribution of population (provisional population totals). New Delhi: Registrar General \& Census Commissioner, India. 
Centre for Policy Research. (2014) Rural local body core functions and finances - A study for the fourteenth Finance Commission. Delhi: Centre for Policy Research.

Cobb, T.A. and Margulies, N. (1981) Organization development: A political perspective. The Academy of Management Review, 6 (1), 49-59.doi: https://doi.org/10.2307/257140 and https://doi.org/10.5465/AMR.1981.4287998

Deming, W.E. (n.d.) Deming Institute PDSA. s.l., Ketchum, Idaho: The W. Edwards Deming Institute. Available at: https://www.deming.org/theman/theories/pdsacycle.

Fernandez, S. and Rainey, H.G. (2006) Managing successful organizational change in the public sector. Public Administration Review, 66 (2), 168-176. doi: https://doi.org/10.1111/j.1540-6210.2006.00570.x

Gabris, G.T. and Golembiewski, R.T. (1996) The practical application of organization development to local governments. In: Gargan, J.J. (ed) Handbook of local government administration (pp. 71-100). New York: Marcel Dekker, Inc.

Government of India. (1992) The Constitution (Seventy-Third Amendment) Act, 1992. Available at: http://indiacode.nic.in/coiweb/amend/amend73.htm [Accessed 15 May 2015].

Government of Karnataka. (1993) The Karnataka Panchayat Raj Act, s.l.: Karnataka Gazette Extraordinary.

Greiner, L.E. (1998) Evolution and revolution as organizations grow. In: Burke, W.W., Lake, G.D. and Paine, J.W. (eds) Organization change: A comprehensive reader (pp. 1-16). San Francisco: Jossey-Bass.

Johnson, C. (2003) Decentralisation in India: Poverty, politics and Panchayati Raj. London: Overseas Development Institute.

Lewin, K. (1946) Action research and minority problems. Journal of Social Issues, 2 (4), 34-46. doi: https://doi.org/10.1111/j.1540-4560.1946.tb02295.x

O'Brien, R. (2001) An overview of the methodological approach of action research. In: Richardson, R. (ed) Theory and practice of action research. Joao Pessoa, Brazil: Universidade Federale da Paraiba.

Perry, J.L. and Rainey, H.G. (1988) The public-private distinction in organization theory: A critique and research strategy. The Academy of Management Review, 13 (2), 182-201. doi: https://doi.org/10.5465/AMR.1988.4306858 and https://doi.org/10.2307/258571

Planning Commission. (2008) Manual for integrated district planning. New Delhi: Government of India.

Rietbergen-McCracken, J. and Narayan, D. (1998) Participation and social assessment:Tools and techniques. Washington D.C.: The World Bank.

Schneider, B., Brief, A.P. and Guzzo, R.A. (1996) Creating a climate and culture for sustainable organizational change. In: Burke, W.W., Lake, D.G. and Paine, J.W. (eds) Organization change:A comprehensive reader (pp. 1-17). San Francisco: Jossey-Bass. doi: https://doi.org/10.1016/s0090-2616(96)90010-8

Scott-Villiers, P. (2002) The struggle for organisational change: How the actionaid accountability, learning and planning system emerged. Development in Practice, 12 (3/4), 424-435. doi: https://doi.org/10.1080/0961450220149771

Second Administrative Reforms Commission. (2007) Sixth report-local governance. Delhi: Government of India.

Sminia, H. and van Nistelrooij, A. (2010) Guest editorial. Journal of Change Management, 10 (4), 387-391. doi: https://doi.org/10.1080/14697017.2010.516484

Srivastava, S. (2014a) Nurturing panchayats to grow - the gram panchayat organisation development projecta process document. Sudha Menon ed. Bengaluru: CDLG, Avantika Foundation.

Srivastava, S. (2014b) The gram panchayat organisation development project. In: Verma, K., Bisht, B. and Cronin, A. (eds) Decentralised governance in water and sanitation in rural India (pp. 233-259). New Delhi: Academic Foundation.

Weick, K.E. and Quinn, R.E. (1999) Organizational change and development. Annual Review of Psychology, 361-386. doi: https://doi.org/10.1146/annurev.psych.50.1.361 